\title{
PENGOLAHAN AIR DI DESA KARANG BUAH KECAMATAN BELAWANG KABUPATEN BARITO KUALA
}

\author{
Muhammad Firman, Muhammad Irfansyah, Heri Irawan, Muhammad \\ Suprapto, dan Saifullah Arief \\ Fakultas Teknik, Universitas Islam Kalimantan MAB \\ Email:firmanuniska99@gmail.com
}

\begin{abstract}
Interest Service to the public about solar power plants (PLTS) so that the public understands and knows solar power plant (SPP), increase public understanding of the importance of solar power plants (PLTS) that, while the benefits to be achieved in this activity is to society its target skills and knowledge in assembly and maintenance of a series of solar power plants (PLTS) so that when applied mistakes. Establishment of cooperation between the community, the village government and Studies Program Faculty of Engineering Uniska. As for Tim will add to the experience in training activities assembly and maintenance of solar power plants.

The method will be used to achieve the goals that have been implemented are: using the training methods of assembly and maintenance of solar power plants directly with solar panels example demonstrated by the team. So with this training method is expected the participants enthusiastically followed and training materials will absorb well.

From the results of the training can be concluded among other things during the training process to be followed can be absorbed $100 \%$ or all the participants, $20 \%$ of participants who attended or 3 people who want to use solar power for the consumption of their homes by asking what the price of a set of solar power until ready to use and implementation of devotion that will come can be developed into other areas in the vicinity of this devotion, of course, with a bigger budget so that citizens who join the training could be more.
\end{abstract}

Keywords: training, skills, solar

\section{PENDAHULUAN}

Dalam rangka penyediaan air bersih dan sehat bagi masyarakat pedesaan yang mana kualitas air tanahnya buruk serta belum mendapatkan pelayanan air minum dari Perusahaan Air Minum, perlu memasyarakatkan alat pengolah air minum sederhana yang murah dan dapat dibuat oleh masyarakat dengan menggunakan bahan yang ada dipasaran setempat. Alat pengolah air bersih tersebut adalah tiga buah bak penampung yang berfungsi sebagai saringan air sungai atau rawa yang akan dijadikan air layak pakai dan layak minum. Cara pengolahannya tidak menggunakan bahan kimia. Secara fisik air bersih harus jernih, tidak berbau dan tidak berasa. Selain itu juga suhu air bersih sebaiknya sama dengan suhu udara atau kurang lebih 
$25{ }^{\circ} \mathrm{C}$, dan apabila terjadi perbedaan maka batas yang diperbolehkan adalah $25{ }^{\circ} \mathrm{C} \pm 30{ }^{\circ} \mathrm{C}$. Batas maksimum kekeruhan air yaitu 25 NTU dan warna air 50 TCU (Quddus, 2014). (Dengan, Fisika, Gusdi, Wita, \& Septiana, 2017)

Dari analisis situasi di atas maka dapat dirumuskan permasalahan sebagai berikut: Bagaimana air yang digunakan dapat memenuhi standart dan kualitas air yang dihasilkan layak pakai dan layak minum?. Sedangkan tujuannya adalah: a. Supaya masyarakat dapat memenuhi kebutuhan air bersihnya sendiri, terutama untuk mandi, cuci dan lain-lain. b. Supaya masalah yang selama ini dihadapi oleh masyarakat kerena kesulitan air bersih dapat teratasi.

Dan manfaat yang ingin dicapai dalam kegiatan ini adalah untuk menghasilkan air dengan kualitas yang layak untuk mencuci, mandi, minum dan lain-lain. sehingga masyarakat tidak perlu membeli air buat keperluan mereka sehari-hari.

\section{KHALAYAK SASARAN}

Sasaran utama kegiatan ini adalah masyarakat dengan cara menyebarluaskan teknologi pengolahan air sederhana untuk mengolah air gambut atau air sungai, yang dapat digunakan di daerah yang terpencil.

\section{METODE PELAKSANAAN KEGIATAN}

Metode yang akan digunakan untuk mencapai tujuan yang telah dicanangkan yaitu: dengan melakukan praktek secara langsung bagaimana pembuatan saringan atau filter air sehingga dapat menghasilkan kualitas air yang sesuai dengan standar layak pakai terutama untuk mandi, mencuci dan memasak. Di akhir kegiatan di harapkan masyarakat dapat menbuat sendiri filter air skala rumah tangga sehingga dapat memenuhi keperluan mereka sehari-hari.

Kegiatan awal yang dilakukan oleh Tim Pengabdian Pada Masyarakat adalah berkoordinasi dengan perangkat Desa Karang Buah Trantang Kecamatan Belawang Kabupaten Barito Kuala untuk melakukan survey di desa tersebut dan menentukan waktu pelaksaaan yang tepat sehingga tidak mengganggu kegiatan atau aktifitas masyarakat di Desa Karang Buah Trantang Kecamatan Belawang Kabupaten Barito Kuala tersebut. Pada saat air pasang yang masuk ke sungai kecil yang berada di Desa Karang Buah Trantang Kecamatan Belawang 
Kabupaten Barito Kuala airnya berasa tawar tetapi warna airnya keruh mengandung zat besi, tetapi ph airnya 7 keatas.. Sedangkan pada saat air sungainya surut rasanya asam, namun warna airnya bening, tetapi phnya kurang dari 7.

Pelaksanaan pengabdian pada masyarakat di Desa Karang Buah Trantang Kecamatan Belawang Kabupaten Barito Kuala dilaksanakan pada bulan Januari 2018 selama 5 hari yaitu tanggal 15 dan 19 Januari 2018. Dan kegiatan berjalan lancar dengan mendapatkan dukungan dari perangkat Desa Karang Buah Trantang Kecamatan Belawang Kabupaten Barito Kuala dengan meminjamkan balai pertemuan masyarakat guna kelancaran pelaksanaan kegiatan. Masyarakat yang berhadir sangat antusias sekali yang ditunjukkan dengan banyaknya pertanyaan yang berhubungan dengan proses pengolahan air bersih yang layak pakai dan juga ke ingin tahuan dari masyarakat mengenai pembuatan filter pengolahan air bersih.

\section{FOTO KEGIATAN}

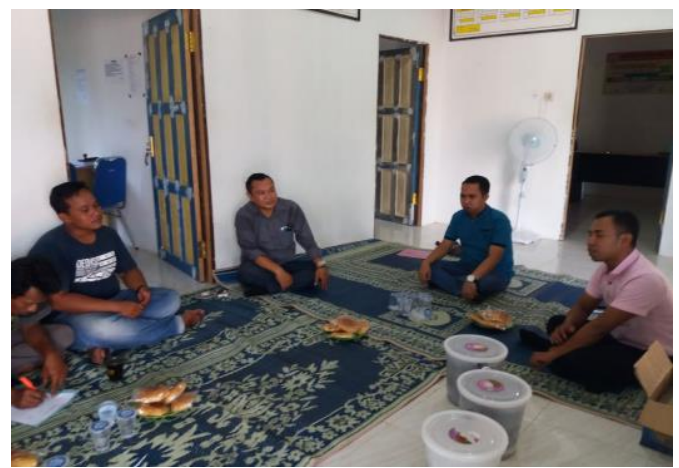

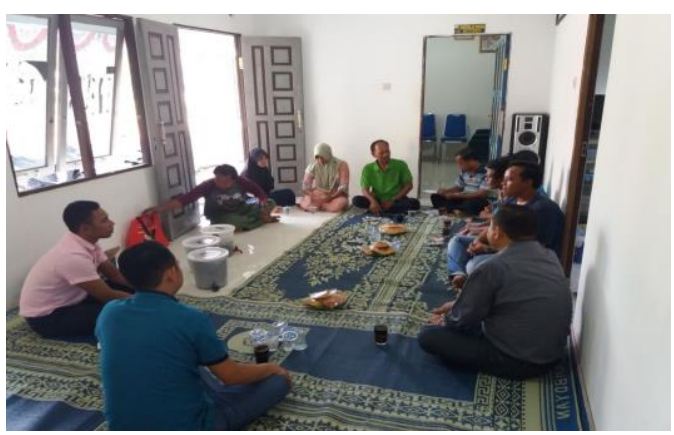

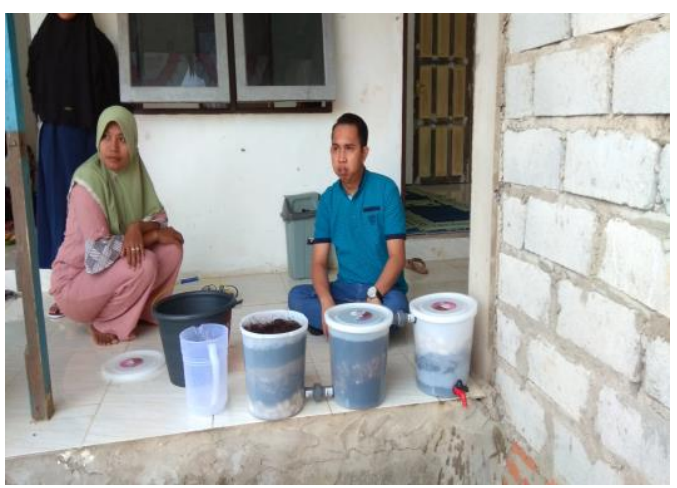

\section{PEMBAHASAN}

Dari hasil pengujian air dapat

disimpulkan:

1. Selama proses percobaan dukungan dan antusias dari masyarakat sangat baik sekali, hal tersebut dibuktikan dengan banyaknya pertanyaan dari para warga tentang proses pengolahan air bersih tersebut dan cara kerja dari filter air.

2. Air yang tadinya keruh setelah melewati pengolahan air atau filter berubah warnanya menjadi lebih jernih. 
3. Air yang tadinya berasa asam setelah melewati pengolahan air atau filter rasanya berubah lebih tawar.

4. Air yang tadinya berbau karat karena mengandung zat besi setelah melewati pengolahan air atau filter rasa zat besi pada airnya sangat jauh berkurang.

\section{DAFTAR PUSTAKA}

Gusdi, R., Wita, H., \& Septiana, U. (2017). Pembuatan Alat Penyaringan Air. Nasional Ecopendon, 4(pembuatan alat penyaring air), 19-21.

Irwansyah, F. S., Susanti, S., \& Windayani, N. (2011). Pengolahan Air Sungai Menjadi Air Layak Konsumsi Menggunakan Kulit Pisang Raja Bulu (Musa paradica). Jurnal Presfektif, 1(1), 19-21.

Quddus, R. (2014). Teknik Pengolahan Air Bersih Dengan Sistem Saringan Pasir Lambat Downflow ), 2(4), 669-675. 